\title{
Covid-19 Hastaları ile Çalışan Evli Hemşire ve Ebelerin Aile İçi Süreçlerindeki Değişimlerin Belirlenmesi
}

\author{
Nurten TERKEŞ ${ }^{1}$ iD Sabriye UÇAN YAMAÇ ${ }^{2}$ (iD)
}

${ }^{1}$ Burdur Mehmet Akif Ersoy Üniversitesi, Bucak Sağlık Yüksekokulu, Hemşirelik Bölümü, Burdur, Türkiye, nurtenterkes@gmail.com (Corresponding Author/Sorumlu Yazar)

${ }^{2}$ Burdur Mehmet Akif Ersoy Üniversitesi, Bucak Sağlık Yüksekokulu, Ebelik Bölümü, Burdur, Türkiye, suyamac@mehmetakif.edu.tr

\begin{tabular}{|c|c|}
\hline Makale Bilgileri & ÖZ \\
\hline $\begin{array}{l}\text { Makale Geçmişi } \\
\text { Geliş: 20.01.2021 } \\
\text { Kabul: } 27.03 .2021 \\
\text { Yayın: } 25.08 .2021\end{array}$ & $\begin{array}{l}\text { Amaç: Çalışmamızın amacı, Covid-19 hastaları ile çalş̧an evli hemşire ve ebelerin aile içi süreçlerindeki } \\
\text { değişimleri belirlemektir. } \\
\text { Yöntem: Araştırmamız Kasım 2020-Ocak } 2021 \text { tarihleri arasında çalışmayı kabul eden evli ebe ve hemşirelerle } \\
\text { yürütülmüşș̈r. Veriler "Hemşire ve Ebelerin Kişisel özellikleri ve Covid-19 sürecinde aile içi süreçleri ile ilgili } \\
\text { yaşadıkları deneyimleri "içeren anket formu ile "online "olarak toplanmıştır. }\end{array}$ \\
\hline $\begin{array}{l}\text { Anahtar Kelimeler: } \\
\text { Hemşire, } \\
\text { Ebe, } \\
\text { Covid 19, } \\
\text { Aile içi süreç, } \\
\text { Pandemi. }\end{array}$ & $\begin{array}{l}\text { Bulgular: Pandemi sürecinde araştırmaya katılan hemşire ve ebelerin \%35.3'ünün aile sürecinin olumsuz } \\
\text { etkilendiği, \%97.6'sının Covid-19'u ailesine bulaştırma kaygısı yaşadığı, \%42.4'ünün aile sürecinde değişiklik } \\
\text { olduğu ve bu değişikliklerin \%58.3'ünün eşinden/çocuklarından ayrı kalmak zorunda kalması, \%22.2 aile içi } \\
\text { çatışmalar yaşaması olarak belirtilmektedir. Araştırmaya katılan hemşire ve ebelerin çocuk sahibi olma durumu, } \\
\text { eğitim durumu, mesleği ve meslekteki çalışma süresi ile aile içi süreçte değişim yaşama durumu arasında } \\
\text { istatistiksel olarak anlamlı fark olduğu saptanmıştır. } \\
\text { Sonuç ve Öneriler: Bu pandemik süreçte, hemşire ve ebelerin aile içi süreçlerinde değişimler yaşadığı, yaşanılan } \\
\text { değişimlerin nedeni olarak virüsü ailelerine bulaştırma korkusu olduğu görülmektedir. Hemşire ve ebelerin aile içi } \\
\text { süreçlerinin korunması için kaygılarının azaltılmasına yönelik tedbirlerin alınmasının önemli olduğu } \\
\text { düşünülmektedir. }\end{array}$ \\
\hline
\end{tabular}

\section{Determine the Changes in the Family Processes of Married Nurses and Midwives Working with Covid-19 Patients}

\section{Article Info}

\section{Article History}

Received: 20.01.2021

Accepted: 27.03.2021

Published: 25.082021

Keywords:

Nursing,

Midwife,

Covid 19,

Family process,

Pandemic.

\section{ABSTRACT}

Purpose: Our study aims to determine the changes in the family processes of married nurses and midwives working with Covid-19 patients.

Method: Our research was conducted with married midwives and nurses who accepted to work between November 2020 and January 2021. The data were collected "online" with a questionnaire containing "Personal characteristics of nurses and midwives and their experiences in family processes during the Covid-19 process". Results: During the pandemic process, $35.3 \%$ of the nurses and midwives who participated in the study harmed the family process, $97.6 \%$ had anxiety about transmitting Covid-19 to their family, $42.4 \%$ had changes in the family process, and $58.3 \%$ of these changes were from their spouse/children. Also, It is stated as having to remain separated and experiencing domestic conflicts in $22.2 \%$. There was a statistically significant difference between the nurses and midwives in the number of children, educational status, the profession, and the duration of their employment, and the state of experiencing a change in the family process.

Conclusion and Recommendations: In this pandemic process, it is seen that nurses and midwives have experienced changes in their family processes and there is a fear of infecting their families. It is thought that it is important to take measures to reduce the anxiety of nurses and midwives to protect their family processes.

Atıf/Citation: Terkeş, N. \& Uçan Yamaç, S. (2021). Covid-19 hastaları ile çalışan evli hemşire ve ebelerin aile içi süreçlerindeki değişimlerin belirlenmesi, Genel Sağllk Bilimleri Dergisi, 3(2), 102-111.

"This article is licensed under a Creative Commons Attribution-NonCommercial 4.0 International License (CC BY-NC 4.0)" 


\section{GİRIŞ}

Aralık 2019'un başlarında, Çin'in Hubei eyaletinin Wuhan şehrinde 2019 korona virüsü (COVID-19) ortaya çıkmıştır. O tarihten itibaren, yerel ve ulusal hükümetler, hastalığın ilerlemesini durdurmak için bir çok alanda önlemler almaya başlamıştır (Zhu vd., 2020; Chen vd., 2020). Dünya Sağlık Örgütü, COVID-19 salgınını 30 Ocak'ta "uluslararası boyutta halk sağlı̆̆1 acil durumu" olarak sınıflandırmış ve 11 Mart'ta küresel salgın (pandemi) olarak tanımlamıştır. Ülkemizde COVID-19 ile ilgili çalışmalar 10 Ocak'ta başlamış ve 22 Ocak’ta T.C. Sağlık Bakanlığı Bilimsel Danışma Kurulu ilk toplantısı gerçekleştirilmiş, alınan önlemler ile ilk COVID-19 vakası 11 Mart'ta görülmüştür (Türkiye Cumhuriyeti Sağlık Bakanlığı [TCSB], 2020). 5 Aralık 2020 tarihi itibari ile dünyada 66390508 Covid-19 vakası ve 1527498 ölüm, ülkemizde ise 765997 Covid-19 vakası ve 14509 ölüm görülmektedir (worldometers.info, 2020).

Pandemik süreçte kısa sürede bir çok hastaya virus bulaşması ve yoğun bakıma yatan hasta sayısının artmasıyla birlikte "bakım" vermenin, "bakım vericilerin" önemi daha net ortaya çıkmıştır (Hachisu ve Suzuki, 2018; Pedrazza vd., 2018). Hastaneye yatan hastalarla uzun süre temas kuran sağlık profesyonelleri içinde en çok temas kuranların hemşire ve ebeler olduğu belirtilmektedir (Choi vd, 2020; Jackson vd., 2020; She vd., 2020; Smith vd., 2020). Hemşire ve ebelerin Covid-19 gibi bulaşıcı hastalıkların olduğu bu pandemik dönemde dahi kendilerini güvende hissettikleri sürece mesleklerini iyi bir şekilde yapmaya devam etmektedirler (Pedrazza vd., 2018). Ancak hemşire ve ebeler bir taraftan hastalarına kaliteli bakım sağlamaya çalışırken diğer yandan bu virüsü ailelerine bulaştırma korkusuyla yüz yüze kalmışlardır (Polat ve Coşkun, 2020). Literatür incelendiğinde ebe ve hemşirelerin eve döndüklerinde aile üyelerine Covid-19 virüsü bulaştırma korkusu nedeniyle aile süreçlerinde bazı değişimler yapmak zorunda kaldıkları belirtilmektedir. Bu değişimlere örnek olarak; aile ve yakınlarından ayrı kalma, eve geç gitme, çocuklarını aile büyüklerine emanet etme verilebilinir (Yüncü ve Yılan, 2020; Adams ve Walls, 2020). Bu nedenle pandemiye yönelik aile içi sürece ilişkin ebe ve hemşirelerin yaşadıkları değişimlerin belirlenmesi, gerekli koruyucu ve iyileştirici önlemlerin alınmasının ebe ve hemşirelerin, alinenin ve toplumun sağlığı açısından yararlı olabileceği düşünülmektedir.

\section{YÖNTEM}

\section{Araştırma Modeli}

$\mathrm{Bu}$ araştırma ülkemizde Covid-19 hastaları ile çalışan evli hemşire ve ebelerin aile içi süreçlerindeki değişimleri belirlemek amacıyla tanımlayıcı ve kesitsel biçimde yapılmıştır.

\section{Örneklem}

Araştırmanın çalışma evrenini, Türkiye'nin tüm kamu ve özel hastanelerinde Covid 19 test sonucu pozitif çıkan hastaların yattığı ünitelerde çalışan evli hemşire ve ebeler oluşturmuştur. Ancak sadece koronavirüs pozitif hastaların bulunduğu servislerde çalışan hemşire ve ebelerin sayısına erişilememiştir. Bu nedenle örneklem hesabı 2020 yılında kamu hastanelerinde çalışan tüm hemşire ve ebeler (209.438) üzerinden Sample Size Calculator programında yapıldı. Programda tip 1 hata 0.05 ve güç \%95 alındığında 136 kişi olarak bulundu. Seçkisiz örnekleme yöntemi kullanılarak Kasım 2020-Ocak 2021 tarihleri arasında evli olan, çalışmaya katılmayı kabul eden ve internet ortamındaki anketi tam olarak dolduran 85 kişiye ulaşılabilmiştir. Anketler hemşire ve ebelere Google Formlar üzerinden online olarak gönderilmiştir.

\section{Veri Toplama Araçları ve Süreçleri}

Veri toplama aracı olarak katılımcıların cinsiyetleri, yaşları, medeni durumları, eğitim 
durumları, meslekleri ve meslekteki çalışma yıllarını içeren toplam 8 sorudan oluşan kişisel bilgi formu ve yine araştırmacılar tarafından literatür taranarak hazırlanan Hemşire ve Ebelerin Covid19 sürecinde aile içi süreçleri ile ilgili yaşadıkları deneyimleri sorgulayan 7 soruluk anket formu kullanıldı (Galehder vd., 2020; Adams ve Walls, 2020; Polat ve Coşkun, 2020; Yüncü ve Yılan, 2020).

\section{Verilerin Analizi}

Araştırmadan elde edilen veriler bilgisayara aktarılarak, SPSS (21.0) istatistik paket programına istatistiksel analizler yapılmıştır. Veriler, yüzdelik, ortalama, standart sapma ve kikare testi ile değerlendirilmiştir. Elde edilen p değeri $<0.05$ olduğunda analiz istatistiksel olarak anlamlı kabul edilmiştir.

\section{Etik}

Araştırmanın yürütülebilmesi için, araştırmaya başlamadan önce Burdur Mehmet Akif Ersoy Üniversitesi Girişimsel Olmayan Klinik Araştırmalar Etik Kurulu'ndan (Tarih: 04.11.2020; Karar No: GO 2020/285) etik onay alındı. Çalışmanın yapılması için Sağlık Bakanlığı Bilimsel Araştırma Değerlendirme Komisyonu'ndan onay alınmıştır. Katılımcılara çevrimiçi bir anket bağlantısı ile ulaşıldı ve çalışmaya başlamadan önce katılımcıların onamları çevrimiçi bağlantı ile alınd1.

\section{BULGULAR}

Araştırmaya katılan hemşire ve ebelerin kişisel özelliklerine göre dağılımına baktığımızda yaş ortalaması $34.81 \pm 7.55, \% 44.7$ 'sinin 30 ila 40 yaşları arasında, \%91.7'sinin kadın, \%72.9'unun çocuk sahibi olduğu, çocuk sahibi olanların \%48.4'ünün 2 çocuğa sahip olduğu, \%69.4'ünün üniversite mezunu olduğu görülmektedir. Ayrıca araştırmaya katılan bireylerin \%69.4'ünün hemşire, \%56.5'nin meslekteki çalışma süresinin 10 yıldan fazla olduğu ve \%31.8'inin yoğun bakımda çalıştığı bulunmuştur (Tablo 1).

Tablo 1. Hemşire ve Ebelerin Kişisel Özelliklerine Göre Dağılımı (n=85)

\begin{tabular}{|c|c|c|}
\hline Kişisel Özellikler & n & $(\%)$ \\
\hline Yaş $(\overline{\mathbf{X}} \pm \mathrm{SS})$ & \multicolumn{2}{|c|}{$34.81 \pm 7.55$} \\
\hline$<30$ & 26 & 30.6 \\
\hline $30-40$ & 38 & 44.7 \\
\hline$>40$ & 21 & 24.7 \\
\hline \multicolumn{3}{|l|}{ Cinsiyet } \\
\hline Kadın & 78 & 91.7 \\
\hline Erkek & 7 & 8.3 \\
\hline \multicolumn{3}{|l|}{ Çocuk sahibi olma durumu } \\
\hline Evet & 62 & 72.9 \\
\hline Hayır & 23 & 27.1 \\
\hline \multicolumn{3}{|l|}{ Kaç çocuğa sahip olduğu } \\
\hline 1 & 25 & 40.3 \\
\hline 2 & 30 & 48.4 \\
\hline 3 ve üzeri & 7 & 11.3 \\
\hline \multicolumn{3}{|l|}{ Eğitim durumu } \\
\hline Sağlık meslek lisesi & 6 & 7.1 \\
\hline Ön lisans & 10 & 11.7 \\
\hline Lisans & 59 & 69.4 \\
\hline Lisansüstü & 10 & 11.8 \\
\hline \multicolumn{3}{|l|}{ Mesleği } \\
\hline Hemşire & 59 & 69.4 \\
\hline Ebe & 26 & 30.6 \\
\hline
\end{tabular}




\begin{tabular}{lcc} 
Meslekteki çalışma süresi & & 18.8 \\
5 yıldan az & 16 & 24.7 \\
$5-10$ yıl & 21 & 56.5 \\
10 yıldan fazla & 48 & 31.8 \\
Çalıştığı Bölüm & & 23.5 \\
Yoğun bakım & 27 & 11.7 \\
Klinik & 20 & 8.2 \\
Doğumhane & 10 & 8.2 \\
Acil & 7 & 8.2 \\
Poliklinik & 7 & 4.7 \\
Aile sağlı̆̆ı merkezi & 7 & 3.5 \\
İlçe Sağlık Müdürlüğü & 4 & 3 \\
Filyasyon & 3 & \\
\hline
\end{tabular}

Hemşire ve ebelerin Covid-19 süreci görüşlerini değerlendirdiğimizde katılımcıların \%40'ının pandemi nedeniyle birim/görev değişikliği yaşadığı, \%31.8'inin haftalık çalışma saatinin arttığ1, Covid-19 sürecinin katılımcıların \%91.7'sinin psikolojisini çok kötü etkilediği, Covid-19 sürecinde katılımcıların \%52.9'unun aile süreci etkilenmezken, \%35.3'ünün olumsuz etkilendiği görülmektedir. Araştırmaya katılanların \%97.7'sinin Covid-19'u ailesine bulaştırma kaygısı yaşadığı, \%42.4'ünün aile sürecinde değişiklik olduğu ve bu değişikliklerin \%58.3'ünün eşinden/çocuklarından ayrı kalmak zorunda kalması, \%22.2'sinin aile içi çatışmalar yaşaması, \%11.1'nin çocuklarına eşinin bakması ve \%8.3'ünün çocuklarının evinde yalnız kalması olarak belirtilmektedir (Tablo 2).

Tablo 2. Hemşire ve Ebelerin COVID-19 Süreci ile İlgili Görüşleri (n: 85)

\begin{tabular}{|c|c|c|}
\hline & $\mathbf{n}$ & $(\%)$ \\
\hline \multicolumn{3}{|l|}{ Pandemi nedeniye birim/görev değişikliği yaşama durumu } \\
\hline Evet & 34 & 40.0 \\
\hline Hayır & 51 & 60.0 \\
\hline \multicolumn{3}{|l|}{ Covid-19 pandemisinde çalışma saatinde değișiklik durumu } \\
\hline Haftalık çalışma saati azaldı & 17 & 20.0 \\
\hline Değişmedi & 41 & 48.2 \\
\hline Haftalık çalışma saati arttı & 27 & 31.8 \\
\hline \multicolumn{3}{|l|}{ COVID-19 genel olarak "psikolojisini" etkileme durumu } \\
\hline Cok kötü & 78 & 91.7 \\
\hline Kötü & 7 & 8.3 \\
\hline \multicolumn{3}{|l|}{ Pandemi Sürecinin aile ilisskisini etkileme durumu } \\
\hline Olumlu & 10 & 11.8 \\
\hline Olumsuz & 30 & 35.3 \\
\hline Etkilemedi & 40 & 52.9 \\
\hline \multicolumn{3}{|l|}{ Covid-19'u ailesine bulaştırma kaygısı } \\
\hline Evet & 83 & 97.7 \\
\hline Hayır & 2 & 2.3 \\
\hline \multicolumn{3}{|l|}{ Aile sürecinde değişiklik yaşama durumu } \\
\hline Evet & 36 & 42.4 \\
\hline Hayır & 49 & 57.6 \\
\hline \multicolumn{3}{|l|}{ Covid pandemisinde aile sürecinde yașanan değișiklikler } \\
\hline Eşimden/çocuklarımdan ayrı kalmak zorunda kaldım & 21 & 58.3 \\
\hline Aile içi çatışmalar yaşadık & 8 & 22.2 \\
\hline Çocuklarıma eșim baktı & 4 & 11.2 \\
\hline Çocuklarım evde yanlız kaldı & 3 & 8.3 \\
\hline
\end{tabular}

Araştırmaya katılan hemşire ve ebelerin aile içi süreçlerinde değişim yaşama durumları ile tanıtıcı özellikleri karşılaştırıldığında, çocuk sahibi olma durumu, eğitim durumu, mesleği ve meslekteki çalışma süresine göre aile içi süreçte değişim yaşama durumları arasındaki farkın istatistiksel olarak anlamlı olduğu bulunmuştur $(\mathrm{p}<0.05)$. Diğer taraftan yaş ve cinsiyet ile aile içi süreçte değişim yaşama durumları arasında istatistiksel olarak anlamlı fark olmadığı görülmektedir (p>0.05) (Tablo 3). 
Tablo 3. Hemşire ve Ebelerin Aile İçi Süreçlerde Değişim Yaşama Durumları ile Tanıtıcı Özelliklerinin Karşılaştırması (n: 85)*

\begin{tabular}{|c|c|c|c|c|c|}
\hline \multirow[t]{3}{*}{ Tanıtıcı Özellikler } & \multicolumn{4}{|c|}{ Aile İçi Süreçlerde Değişim Yaşama Durumu } & \multirow[t]{3}{*}{$\mathrm{P}^{*}$} \\
\hline & \multicolumn{2}{|c|}{ Evet } & \multicolumn{2}{|c|}{ Hayır } & \\
\hline & $\mathbf{n}$ & $\%$ & $\mathbf{n}$ & $\%$ & \\
\hline \multicolumn{6}{|l|}{ Yaş } \\
\hline$<30$ & 14 & 53.8 & 12 & 46.2 & 0.327 \\
\hline $30-40$ & 15 & 39.5 & 23 & 60.5 & \\
\hline$>40$ & 7 & 33.3 & 14 & 66.7 & \\
\hline \multicolumn{6}{|l|}{ Cinsiyet } \\
\hline Kadın & 31 & 39.7 & 47 & 60.3 & 0.104 \\
\hline Erkek & 5 & 71.4 & 2 & 28.6 & \\
\hline \multicolumn{6}{|l|}{ Cocuk sahibi olma durumu } \\
\hline Evet & 20 & 32.3 & 42 & 67.7 & 0.002 \\
\hline Hayır & 16 & 69.6 & 7 & 30.4 & \\
\hline \multicolumn{6}{|l|}{ Eğitim durumu } \\
\hline Lise & 1 & 16.7 & 5 & 83.3 & 0.000 \\
\hline Ön lisans & 9 & 90.0 & 1 & 10.0 & \\
\hline Lisans & 18 & 30.5 & 41 & 69.5 & \\
\hline Yükseköğretim & 8 & 80.0 & 2 & 20.0 & \\
\hline \multicolumn{6}{|l|}{ Mesleği } \\
\hline Hemşire & 31 & 52.5 & 28 & 47.5 & 0.005 \\
\hline Ebe & 5 & 19.2 & 21 & 80.8 & \\
\hline \multicolumn{6}{|l|}{ Meslekteki çalıșma süresi } \\
\hline 5 yildan az & 6 & 37.5 & 10 & 62.5 & 0.001 \\
\hline $5-10$ y1l & 16 & 76.2 & 5 & 23.8 & \\
\hline 10 yildan fazla & 14 & 29.2 & 34 & 70.8 & \\
\hline
\end{tabular}

* Ki-kare testi

\section{TARTIŞMA}

$\mathrm{Bu}$ çevrimiçi tabanlı kesitsel çalışma, Covid-19 hastaları ile çalışan hemşire ve ebelerin aile içi süreçlerindeki değişimleri belirlemeye yönelik kanıt sağlamıştır. Çalışmamızda evli hemşire ve ebelerin Covid-19 sürecine ilişkin deneyimlerini değerlendirdiğimizde katılımcıların \%40'ının pandemi nedeniyle birim/görev değişikliği yaşadığı, \%31.8'inin haftalık çalışma saatinin arttığ bildirilmektedir. Yüncü ve Yılan (2020)'ın yaptığı çalışmaya göre katılımcıların tamamına yakınının çalışma koşullarında değişiklik yaşadığı belirtilmiştir. Bir başka çalışmada, COVID-19 salgını sırasında hasta sayısının artmasıyla birlikte hemşirelerin çalışma saatlerinin 1,5-2 kat artmış ve çalışma saatlerinin artmasına paralel olarak iş yükü de artmıştır (Sun vd., 2020). Almanya'da yapılan bir çalışmada pandemi nedeniyle özellikle acil servis, yoğun bakım üniteleri ve Covid-19 servislerinde görev yapan sağlık çalışanlarının çalışma süresinin arttığı bildirilmektedir (Kramer vd., 2021). Bu sonuçların yanı sıra Halcomb ve diğerleri (2020)'nin çalışmasında, katılımcıların yaklaşık yarısının Covid servisleri, yoğun bakım ve acil servisler dışında çalışan sağlık çalışanlarının pandeminin başlangıcından bu yana çalışma saatlerinin azaldığını, işten ayrılma tehdidinde bulunduğunu ya da fiili işten çıkarıldığını bildirdi. Ayrıca aynı çalışma sonuçlarına göre çalışanlara kendi görevleri dışında ek sorumluluk verildiği de belirtilmektedir (Halcomb vd., 2020).

Çalışmamızda covid-19 sürecinin katılımcıların tamamına yakınının psikolojisini çok kötü etkilediği bildirilmektedir. Bir çalışmada sağlık çalışanlarının fiziksel güvenlik korkusunun ötesinde, pandeminin psikolojik etkisine yönelik yoğun endişe yaşadıkları belirtilmektedir (Halcomb vd., 2020). Pandemik süreçten dolayı katılımcıların dışlanma yaşadığı, covid-19 virüsü açısından potansiyel taşıyıcılar olarak gördükleri için ailelerininde ayrımcılığa uğradı belirtilmektedir (Kim, 2018). Ayrıca Liu ve diğerleri (2020)'nin yaptığı çalışmada, covid-19 tanılı hastalara bakım veren hemşirelerin iş 
yükünün ağırlığ 1 ve sürekli kişisel koruyucu ekipman kullanma zorunluluğu nedeniyle bunalmışlık ve bitkinlik hissi, enfekte olma ve ailesine bulaştırma korkusu yaşadıkları görülmektedir (Liu vd., 2020). Ayrıca yaşanan olumsuz psikolojik durumun sağlık çalışanlarının bir çoğunun virus bulaşma riskine karşı ailerlerinden uzak durumak zorunda hissetmelerinden kaynaklı olabileceği bildirilmektedir (Kang vd., 2020). Bu tür durumlarında hemşire ve ebelerin psikolojik olarak kötü hissetmelerine sebep olabileceği düşünülmektedir. Ayrıca bu olumsuz durum iş doyumunun azalmasına ve tükenmişliğe neden olabilmektedir.

Covid-19 sürecinde katılımcıların yarıya yakınının aile sürecini olumsuz etkilendiği görülmektedir. Bakmakla yükümlü oldukları çocuklarının ve diğer akrabalarının bakım gereksinimlerini karşılayamadıkları belirtilmektdir (Costantini vd., 2020). Türk Hemşireler Derneği'nin 27 Nisan 2020'de yayımladığı covid-19 Mevcut Durum Analizi Raporu'nda eşi sağlık çalışanı ya da asker olan hemşirelerin çocuklarının bakımı için izin almada yaşadıkları sorunlar covid19 tanılı hastalara bakım veren hemşirelerin en fazla yaşadıkları güçlüklerden biri olduğu belirtilmektedir (Türk Hemşireler Derneği [THD], 2020). Ayrıca ebelerin çalıştıkları birimlerde ve çalışma saatlerinde de değişimler olmuştur. Filyasyon ekiplerinde aktif rol oynamışlar ve çalışma saatteleri buna paralel olarak artış göstermiştir. Ebelerin filyasyon ekibinde yer alması nedeniyle ailelerine bulaş riskini önlemek için ailelerinden uzak kalmak zorunda hissetmişlerdir. Hem hemşirelerin hem de ebelerin karşılaştıkları bu tür durumların aile sürecini olumsuz etkileyebileceği düşünülmektedir.

Çalışmamızda, araştırmaya katılanların neredeyse tamamının Covid-19'u ailesine bulaştırma kaygısı yaşadığı görülmektedir. Çalışmamıza benzer şekilde 85 İranlı hemşirenin anksiyete belirtilerini araştıran bir çevrimiçi çalışmada, kendileri ve aileleri için yüksek oranda kaygı yaşadıkları belirtilmektedir (Nemati vd., 2020). Liu ve diğerleri (2020)'nin çalışma sonuçlarında da hemşirelerin ailelerine covid-19 bulaştırma korkusu yaşadıklarını bildirmektedir.

Sağlık çalışanlarının bir çoğu ailelerine virus bulaştırma korkusuyla kendilerini ailelerinden izole etmeye karar verdiler (Lorenzo ve Carrisi, 2020). Çalışma bulgularımızda, katılımcıların \%42.4'ünün aile sürecinde değişiklik olduğu ve bu değişikliklerin \%58.3'ünün eşinden/çocuklarından ayrı kalmak zorunda kalması, \%22.2 aile içi çatışmalar yaşaması, \%11.1'nin çocuklarına eşinin bakması ve \%8.3'ünün çocuklarının evinde yalnız kalması olarak belirtilmektedir. Galehdar ve diğerleri (2020) yaptığı veri analizinde, katılımcılar taşıyıcı olma olasıllı̆̆ nedeniyle aile üyeleriyle yakın temas kuramadıklarını, işten eve döndüklerinde hemşirelerde taşıyıcı olma korku ve kaygısının her zaman var olduğunu belirtmişlerdir. Aynı çalışmada katılımcıların deneyimlerine göre bazı hemşireler çocuklarından ayrı kalmak zorunda kaldılar. Çalışmalarında gösterdiği gibi covid-19 pozitif hastalarla bire bir çalışanların ailelerine virüsü bulaştırma korkusu yaşamış, bu nedenle çocuklarından ayrı kalmak durumunda kalmışlardır. Yaşam alanlarının ayrılması, kıyafetlerin değiştirilmesi ve görevden hemen sonra duş alınması gibi destekleyici uygulamalar ve önerilerin kaygıyı azaltmaya yardımcı olabileceği bildirilmektedir (Adams ve Walls, 2020). Ayrıca çalışanların endişeleri gidermek ve süreci daha iyi yönetebilmek için çocuğa sahip sağlık çalışanlarının covid-19 hastalarının bulunduğu servis dışında çalıştırmak gibi bazı önlemlerin alınması gerektiği düşünülmektedir.

$\mathrm{Bu}$ çalışmada araştırmaya katılan hemşire ve ebelerin aile içi süreçlerinde değişim yaşama durumları ile tanıtıcı özellikleri karşılaştırıldığında; çocuk sahibi olmayanların, yüksek eğitim düzeyine sahip olanların, ebelere kıyasla hemşirelerin ve çalışma süresi 10 yıldan az olanların diğer gruplara göre aile süreçlerinde değişim yaşadıkları görülmektedir. Çocuk sahibi olan bireylerin aile bağlarının daha kuvvetli olabileceği akla gelmektedir, bu nedenle aile içi süreçte değişim yaşamadıkları düşünülmektedir. Hemşirelerin pandemik süreçte ebelerden daha uzun süre covid-19'lu hastalarla temas kurduğu bu nedenle ailelerinden ayrı kalmayı daha çok tercih ettikleri 
düşünülmektedir. Çalışma süresi arttıkça sağlık çalışanlarının değişik vakalarla karşılaşmaları, her durumda nasıl davranmaları gerektiğini bilmeleri, kendilerini ve ailerlerini nasıl koruyacaklarını bildiklerini düşünmeleri gibi durumların aile içi süreçlerinde değişim yaşamamalarının nedeni olarak görülmektedir.

\section{SONUÇ ve ÖNERILER}

Sonuç olarak, hemşire ve ebelerin korku ve kaygısının kaynaklarından biri, ailelerinden ayrılmak ve eve dönerken onları enfekte etme korkusudur. Bu nedenle bir çok hemşire ve ebe çocuklarından veya eşlerinden ayrı kalmak zorunda kalıyorlar. Hemşire ve ebelerde yaşanacak sorunlar tüm bakım sistemini etkileyebilir ve hasta bakımını tehlikeye atabileceği düşünülmektedir. Sağlık çalışanlarının devam eden süreçte etkin çalışmalarını sağlamak için aile içi yaşadıkları sorunlara yönelik koruyucu önlemler alınması önemlidir. Hemşire ve ebelerin en az kontaminasyon ihtimalini sağlayarak evlerine güven içinde gitmelerini sağlayabilmak için yetkililerin sağlik çalı̧̧anlarına yönelik örgütsel ve sosyal destek sağlaması, iş yerinden ayrılmadan önce banyo yapma olanakları sağlanması, iş kıyafetlerinin kurumlarında dezenfeksiyonarının sağlanması gibi yeni önlemler almaları gerekmektedir.

Teşekkür: Araştırmanın yürütülmesine destek olan tüm hemşire ve ebelere teşekkür ederiz.

\section{Finansal destek}

Finansal destek alınmamıştır.

\section{Çıkar Çatış̧ması}

Herhangi bir çıkar çatışması bulunmamaktadır.

\section{Yazar Katkıları:}

Tasarım/Design: N.T., S.U.Y. Veri toplama veya veri girişi yapma/Data collection or processing: N.T., S.U.Y.; Analiz ve yorum/Analysis or interpretation: N.T.; Literatür tarama/Literature search: N.T., S.U.Y,.; Yazma/Writing: N.T., S.U.Y.

\section{KAYNAKÇA}

Adams, J. G., \& Walls, R. M. (2020). Supporting the health care workforce during the COVID-19 global epidemic. JAMA, 323, 1439. https://doi.org/10.1001/jama.2020.3972

Chen, S., Yang, J., Yang, W., Wang, C., \& Bärnighausen, T. (2020). COVID-19 control in China during mass population movements at New Year. Lancet. 395 (10226), 764-766. https://doi.org/10.1016/S01406736(20)30421-9

Choi, K. R., Skrine Jeffers, K., \& Logsdon, M. C. (2020). Nursing and the novel coronavirus: Risks and responsibilities in a global outbreak. Journal of Advanced Nursing, Epub Ahead, 1-2. http://doi.org/10.1111/jan.14369

Costantini, M., Sleeman, K. E., Peruselli, C., \& Higginson, I. J. (2020). Response and role of palliative care during the COVID-19 pandemic: a national telephone survey of hospices in Italy. Palliative Medicine, 34(7), 889-895. https://doi.org/10.1177/0269216320920780

Galehdar, N., Toulabi, T., Kamran, A., \& Heydari, H. (2020). Exploring nurses' perception of taking care of patients with coronavirus disease (COVID-19): A qualitative study. Nursing Open. 00:1-9. https://doi.org/10.1002/nop2.616

Hachisu, T., \& Suzuki, K. (2018). Tactile apparent motion through human-human physical touch. In Haptics: Science, Technology, and Applications (pp. 163-174). https://doi.org/10.1007/978-3-319-93445-7_15

Halcomb, E., McInnes, S., Williams, A., Ashley, C., James, S., Fernandez, R., Stephen, C., \& Calma, K. (2020). The experiences of primary healthcare nurses during the COVID-19 pandemic in Australia. Journal of 
Nursing Scholarship, 52(5), 553-563. https://doi.org/10.1111/jnu.12589

Jackson, D., Bradbury-Jones, C., Baptiste, D., Gelling, L., Morin, K., Neville, S., \& Smith, G. D. (2020). Life in the pandemic: some reflections on nursing in the context of COVID-19. Journal of Clinical Nursing, Ahead of Print, 1-3. http://doi.org/10.1111/jocn.15257

Kang, L., Ma, S., Chen, M., Yang, J., Wang, Y., Li, R., Yao, L., Bai, H., Cai, Z., Yang, B. X., Hu, S., Zhang, K., Wang G., Ma, C.,\& Liu, Z. (2020). Impact on mental health and perceptions of psychological care among medical and nursing staff in Wuhan during the 2019 novel coronavirus disease outbreak: A cross-sectional study. Brain, Behavior, and Immunity, (Ahead of print), 87, 11-17. http://doi.org/10.1016/j.bbi.2020.03.028

Kim, Y. (2018). Nurses' experiences of care for patients with middle east respiratory syndrome-coronavirus in South Korea. American Journal of Infection Control, 46(7), 781-787. https://doi.org/10.1016/j.ajic.2018.01.012

Kramer, V., Papazova, I., Thoma, A., Kunz, M., Falkai, P., Schneider-Axmann, T., Hierundar, A., Wagner, E., \& Hasan, A. (2021). Subjective burden and perspectives of German healthcare workers during the COVID-19 pandemic. European Archives of Psychiatry and Clinical Neuroscience, 271 (2), 271-281. https://doi.org/10.1007/s00406-020-01183-2

Liu, Q., Luo, D., Haase, J. E., Guo, Q., Wang, X. Q., Liu, S., .. \& Yang, B. X. (2020). The experiences of health-care providers during the COVID-19 crisis in China: a qualitative study. The Lancet Global Health. 8, e790-e798. https://doi.org/10.1016/S2214-109X(20)30204-7

Lorenzo, D., \& Carrisi, C. (2020). COVID-19 exposure risk for family members of healthcare workers: An observational study. International Journal of Infectious Diseases, 98, 287-289. https://doi.org/10.1016/j.ijid.2020.06.106

Nemati, M., Ebrahimi, B., \& Nemati, F. (2020). Assessment of Iranian nurses' knowledge and anxiety toward COVID-19 during the current outbreak in Iran. Archives of Clinical Infectious Diseases 15 (COVID-19), e102848, 1-5. https://doi.org/10.5812/archcid.102848

Pedrazza, M., Berlanda, S., Trifiletti, E., \& Minuzzo, S. (2018). Variables of individual difference and the experience of touch in nursing. Western Journal of Nursing Research, 40(11), 1614-1637. http://doi.org/10.1177/0193945917705621.

Polat, Ö. P., \& Coşkun, F. (2020). COVID-19 salgınında sağlık çalışanlarının kişisel koruyucu ekipman kullanımları ile depresyon, anksiyete, stres düzeyleri arasındaki ilişkinin belirlenmesi. Batı Karadeniz Tıp Dergisi, 4(2), 51-58. https://dergipark.org.tr/en/download/article-file/1226262

She, J., Jiang, J., Ye, L., Hu, L., Bai, C., \& Song, Y. (2020). 2019 novel coronavirus of pneumonia in Wuhan, China: Emerging attack and management strategies. Clinical and Translational Medicine, 9(1), 19. http://doi.org/10.1186/s40169-020-00271-z

Smith, G. D., Ng, F., \& Ho Cheung Li, W. (2020). COVID-19: Emerging compassion, courage and resilience in the face of misinformation and adversity. Journal of Clinical Nursing, (9-10), 1425-1428. http://doi.org/10.1111/jocn.15231

Sun, N., Wei, L., Shi, S., Jiao, D., Song, R., Ma, L., Wang, H., Wang, C., Wang, Z., You, Y., Liu, S., \& Wang, H. (2020). A qualitative study on the psychological experience of caregivers of COVID-19 patients. American Journal of Infection Control, 48(6), 592-598. https://doi.org/10.1016/j.ajic.2020.03.018

T.C. Sağlık Bakanlığı Halk Sağlığı Genel Müdürlüğü (2020). COVID-19 (SARSCoV2 Enfeksiyonu) rehberi (Bilim Kurulu Çalışması) Erişim Tarihi:12.11.2020 https://covid19bilgi.saglik.gov.tr/depo/rehberler/COVID19_Rehberi.pdf

Türk Hemşireler Derneği (THD). (2020). COVID- 19 mevcut durum analizi raporu. Türk Hemşireler Derneği. Erişim Tarihi: 15.05.2020. https://www.thder.org.tr/uploads/files/EK-SB-Hemsirelerin-Durum-Analizi5.Rapor.pdf.

Wordmeter, 2020. Total coronavirus cases in Turkey and in world. https://www.worldometers.info/coronavirus/country/turkey/

Yüncü, V., \& Yilan, Y. (2020). COVID-19 pandemisinin sağlık çalışanlarına etkilerinin incelenmesi: Bir durum analizi, Ĭgdır Üniversitesi Sosyal Bilimler Dergisi, Ek sayl, 373-401. http://sosbilder.igdir.edu.tr/Makaleler/1669315846_16-Mak-373-401.pdf

Zhu, N., Zhang, D., Wang, W., Li, X., Yang, B., Song, J., Zhao, X., Huang, B., Shi, W., Lu, R., Niu, P., Zhan, F., Ma , X., Wang, D., Xu, W., Wu, G., Gao, G. F., Tan, W., \& China Novel Coronavirus Investigating and Research Team. (2020). A novel coronavirus from patients with pneumonia in China, 2019. New England Journal of Medicine, 382, 727-733. http://doi.org/10.1056/NEJMoa2001017 


\section{EXTENDED ABSTRACT}

Introduction: In early December 2019, the coronavirus emerged in Wuhan, China (Zhu et al., 2020; Chen et al., 2020). The World Health Organization classified the COVID-19 outbreak as a state of emergency in terms of international public health on January 30 and defined it as a global epidemic (pandemic) on March 11 (TCSB, 2020).

In this period when everyone is afraid of approaching each other, healthcare professionals continue to do their profession eagerly as long as they feel safe (Pedrazza et al., 2018: 1630). While healthcare workers take the necessary measures to control the pandemic process, their experiences during the protection and treatment of both themselves and patients have become very important (Polat and Coşkun, 2020: 52). In this period, they had to experience some changes in their family life due to the fear of infecting their family members with the COVID-19 virus. It has been stated that there are situations such as being separated from their family and relatives due to the conditions of isolation, going home late, and entrusting their children to the elders of the family (Yüncü \& Yılan, 2020: 384; Adams \& Walls, 2020: 1440). Therefore, it is considered that determining the changes regarding the intrafamilial process is important in terms of taking necessary measures.

Materials and Methods: This descriptive and cross-sectional study was conducted to determine the changes in the intrafamilial processes of married nurses and midwives providing care for patients with Covid-19 in Turkey. The sample of the study consisted of 85 individuals who accepted to participate in the study between November 2020 and January 2021 and filled out the online questionnaire. A questionnaire questioning the socio-demographic characteristics of the participants and their experiences in terms of intrafamilial processes was used as a data collection tool. The questionnaire was created on Google Forms and sent online to nurses and midwives. The collected data were computerized, and statistical analysis was done using SPSS (21.0) statistical analysis software. The ethical approval was obtained from Burdur Mehmet Akif Ersoy University's Non-Interventional Clinical Research Ethics Committee (Date: 04.11.2020; Decision No: GO 2020/285) before the study. Additional approval was also obtained from the Scientific Research Evaluation Commission of the Ministry of Health to conduct the study.

Findings and Discussion: This online-based cross-sectional study provided evidence to identify changes in intrafamilial processes of nurses and midwives working with Covid-19 patients. In our study, nearly half of the participants had to change their department/assignment due to the pandemic and their weekly working hours increased. Yüncü and Yllan (2020: 388) stated that almost all of the participants experienced changes in their working conditions. In another study, the working hours of nurses increased 1.5-2 times due to the increase in the number of patients during the COVID-19 pandemic, and their workload also increased in parallel with the increase in working hours (Sun et al., 2020: 594). During the pandemic, it is important to support health workers to improve patient care quality, as the increase in the working hours of nurses and midwives may also affect the quality of care.

Nearly half of the participants' intrafamilial processes were negatively affected by the Covid-19 pandemic. They stated that they could not meet the care needs of their dependent children and other relatives (Costantini et al., 2020: 889). According to the report published by the Turkish Nurses Association, nurses whose spouses were healthcare staff or soldiers had problems in taking leave for the care of their children, as one of the most experienced difficulties (THD, 2020). Such situations may affect intrafamilial processes negatively. The determination of such situations that they may experience can help in finding the necessary solutions.

Our result showed that almost all of the participants had anxiety about transmitting Covid-19 to their family members. Therefore, most of them experienced changes in their intrafamilial processes. These changes were being separated from their spouses/children, experiencing family conflicts, and taking care of their children by their spouses. An online study investigated the anxiety symptoms of 85 Iranian nurses and has similar findings, and found that the nurses experienced high levels of anxiety for themselves and their families (Nemati et al., 2020: 2). Some measures, such as employing healthcare professionals with children outside the ward where patients with COVID-19 are hospitalized, should be taken to relieve the concerns of nurses and midwives and to manage the process better.

Also, we compared the nurses and midwives in terms of experiencing changes in their family processes and introductory characteristics. Those who did not have children, those with a high level of education, nurses, and those with a working period of fewer than ten years experience more changes in their family processes compared to other groups. Individuals who have children have stronger family ties, so they do not experience changes in their family processes. Nurses make contact with patients with COVID-19 for a longer time compared to midwives in the pandemic process, and therefore they prefer to stay separated from their families. The situations such as encountering different cases as the working time increases, know how to behave in every 
situation, and think that they know how to protect themselves and their families minimize the changes in their family life.

Conclusion and Suggestions: In conclusion, one of the sources of fear and anxiety of nurses and midwives is the fear of remaining separated from their families and infecting them at home. Therefore, many nurses and midwives have to be separated from their children or spouses. Nurses and midwives should go home safely by minimizing the possibility of contamination. The problems of nurses and midwives may affect the entire care system and put patient care at risk. Considering that Covid-19 disease can affect for months or even years, nurses and midwives need to be supported physically, socially, and psychologically to maintain their working efficiency. It is important to take protective measures for the intrafamilial problems of health staff to ensure that they work effectively. 